\title{
Green Facades and Living Walls-A Review Establishing the Classification of Construction Types and Mapping the Benefits
}

\author{
Mina Radić ${ }^{1, *(1)}$, Marta Brković Dodig ${ }^{2,3}$ and Thomas Auer ${ }^{4, *}$ \\ 1 Independent Scholar, Belgrade 11000, Serbia \\ 2 Faculty VI-Planning Building, Environment, Institute for City and Regional Planning Technical University \\ of Berlin, 10623 Berlin, Germany \\ 3 Faculty for Construction Management, Architecture Department, Union University Nikola Tesla, \\ Belgrade 11000, Serbia \\ 4 Faculty for Architecture, Technical University of Munich, 80333 München, Germany \\ * Correspondence: minaradic@hotmail.com (M.R.); klima@lrz.tu-muenchen.de (T.A.); \\ Tel.: +381-(0)63-117-2223 (M.R.); +49-(0)89-289-22475 (T.A.)
}

Received: 21 June 2019; Accepted: 16 August 2019; Published: 23 August 2019

\begin{abstract}
The green facades and living walls of vertical greenery systems (VGS) are gaining increasing importance as sustainable building design elements because they can improve the environmental impact of a building. The field could benefit from a comprehensive mapping out of VGS types, an improved classification and nomenclature system, and from linking the benefits to a specific construction type. Therefore, this research reviews existing VGS construction types and links associated benefits to them, clearly differentiating empirical from descriptive supporting data. The study adopted a scoping research review used for mapping a specific research field. A systematic literature review based on keywords identified 13 VGS construction types-four types of green facades, nine types of living walls, and ten benefits. Thermal performance, as a benefit of VGS, is the most broadly empirically explored benefit. Yet, further qualitative studies, including human perception of thermal comfort are needed. Improvements in air quality, reduction of noise, positive effects on hydrology, and visual benefits need much further empirical testing, as the current supporting data is mostly descriptive and based on the similarities with green roofs. The educational benefits of VGS has no supporting empirical evidence, while the social benefits have only been empirically evaluated through one identified study. Future progress of the field depends on the adoption of a clear VGS nomenclature system and further qualitative and quantitative empirical testing of VGS benefits, which should be clearly linked to a specific VGS construction type so that cross-comparison of studies is enabled.
\end{abstract}

Keywords: external vertical greenery systems; living walls; green facades; classification of VGS construction types; VGS benefits

\section{Introduction}

In recent decades, there has been an ever-growing number of pressing climate change challenges. Architects and urban planners have been proposing sustainable building designs as an approach that can contribute to the problem's solution, as it has the potential to reduce energy demand, minimize environmental impacts, and alleviate the heat island effect. Green roofs, green facades, and living walls are sustainable building design elements that are steadily gaining in importance and being increasingly widely applied [1-3]. The application of green roofs is a much-established practice throughout the world [4]. On the other hand, the full potential of vertical greenery systems (VGS) — green facades and living walls-is not fully exploited. This is partly because the number of plants that can be used for a 
specific VGS construction type is smaller than the number of plants which are applicable on green roofs. Additionally, the influences of applicable VGS plant varieties is seldom thoroughly mapped [5]. A comprehensive list of manufacturers in different parts of the world also does not exist. Climates in which green facades and living walls are researched are sometimes not specified in studies [6], and evaluation methods are not always clearly laid out. In multi-story buildings, the area under VGS can be up to 20 times bigger than the roof area [7]. Therefore, having green facades and living walls can have more effect on the environmental impact of a building than having green roofs.

Living walls are defined as designed, built, and maintained vegetation elements that potentially have multi-functional and deliberate environmental benefits for their built surroundings [8]. They should not be confused with green facades, as "living walls or green walls are self-sufficient living walls that are attached to the exterior or interior of a building. They differ from green facades (e.g., ivy walls) in that the plants root in a structural support which is fastened to the wall itself. The plants receive water and nutrients from within the vertical support instead of from the ground" [9]. Benefits of VGS could be observed on two levels - on an urban scale and a building scale [10]. Wood et al. listed the benefits of VGS on an urban scale, such as: reduction of the urban heat island effect, improvement of air quality, sequestering of carbon, aesthetic appeal, psychological impact on urban dwellers, providing biodiversity, creating natural animal habitats, and sound deadening [10]. The same group of authors also listed benefits on a building scale, which include improvement of building energy efficiency, indoor environmental quality, internal air quality, air filtration and oxygenation, health, better envelope protection, interior noise reduction, and increased property value [10]. Additional noted benefits are the reduction of stormwater runoff [11], and a variety of positive social effects [12] and educational effects [13]. Loh [14] claims that VGSs can increase biodiversity in urban environments where much ecology has been lost to development.

However, the debate in this field is not without its hindrances. Firstly, confusion between the terms 'living wall', 'green facades', and 'vertical gardens' still exists. Secondly, many same-type constructions appear under different names (names appearing in various research studies, as well as in manufacturers' catalogs). Thirdly, there is a lack of extensive classification of the types of green facades and living walls. Fourthly, the listed benefits are not always supported with empirical data, and where empirical evidence exists, it is not consistently clear which simulations, tools, and procedures have been used for measurement. Fifthly, empirical and descriptive data are not systematically laid out. Consequently, all of these facts in the research arena hinder further progress of the field, thus meaning that following the debate is complicated and contributing to it is challenging. In the practitioners' arena, a more intense application and further testing in the practice of green facades and living walls is potentially hampered.

The importance of this research lies in the following facts: the study firstly systematizes and develops a broader nomenclature of VGSs based on their construction type. Secondly, it proposes a system for derivation of a common name and acronym for each VGS type. Thirdly, it links the types of VGSs and their benefits (clearly differentiating whether empirical or descriptive data is used), and fourthly, it highlights the gaps and proposes potential research avenues for the future.

\section{Literature Review}

Research studies which comprehensively map out VGS types, systematically classify them, and link empirical evidence of their benefits simultaneously are scarce. Generally, research studies either develop a slightly broader classification of green facades and living walls and do not comment on their benefits [15], or analyze only one benefit in depth [16].

Perez et al. [17] provided a basic classification of construction systems, climate influence, plant species, and different operating mechanisms, and classified VGS into green walls and green facades. Hunter et al. [18] only researched different types of green facades, and classified them into 'direct' and 'double-skin' green facades, together with plant trait data, microclimate parameters, and the effect of the green facade on the thermal environment. Perini [19] listed direct and indirect greening systems, as well as indirect greening systems with a planter box as green facade, and living walls based on planter 
boxes, foam substrates, and felt layers. Almost identically, Bustami et al. [20] divided green facades into direct and indirect ones, and living walls into ones with modular trays, a felt system, and horizontal felt system. Susorova and Bahrami [21] classified VGS as green facades and living walls, namely: vegetated mate, hanging pockets, framed boxes modular, wire cage modular, perforated boxes modular, and boxes with cell modular living walls. Koc et al. [22], when classifying green infrastructures, listed bio-walls, green facades, green walls, living walls, vertical landscaping, and vertical vegetation as VGS. Medl et al. [23] divided green facades into direct and indirect ones with ground- or planter-box-based planting, and living walls into continuous ones, modular ones with a pocket planter, or vertical and grid panels, and liner ones with a planter box. Similarly, Manso and Castro-Gomes [15] ventured into providing a broader VGS classification, and Radosavljevic et al. [24] replicated the same categorization. Both studies divide VGS into green facades (traditional green facades as direct ones, and continuous and modular trails as indirect ones), and living walls (lightweight screens as continuous ones, and trays, vessels, planter tiles, and flexible bags as modular ones). A study by Manso and Castro-Gomes [15] provides extremely valuable data regarding the assessment of the advantages and disadvantages of VGS through comparative analysis of their supporting elements, vegetation, growth media, drainage, irrigation, installation and maintenance, environmental performance, and costs. However, their VGS nomenclature is less elaborate and diverse, and each type is not linked with their specific benefits. Moreover, the differentiation of empirical and descriptive data of the benefits was not this study's main focus. The literature review revealed that many different general divisions of VGS exist. Most of the studies identified agree with the general division of VGS in two main categories: green facades and living walls $[15,17,22,25]$. However, the challenge is that many same-type VGS, mostly living walls, keep appearing under different names.

Descriptive studies about VGS benefits could be found, but the benefits in those studies were simply described, and not measured or empirically tested $[13,14,26,27]$. A smaller number of studies contained specific measurements for an analyzed benefit [28-30]. The discussion on VGS benefits is more dispersed, specific benefits are not always linked to a specific VGS type, the list of benefits is long, but the data used to support the findings is descriptive and seldom empirical. As Otelle et al. observes, "greening the cities is not a new approach (i.e., hanging gardens of Babylon), but the benefits are rarely quantified" [31] (p. 3419). Similarly, Coma Arpon [32] states that experimental data for green (living) walls and green facades is scarce, and there is also a lack of studies on energy-saving, the leaf area index of species used, and reduction of noise and foliage thickness, and suggests that: "a disparity in the VGS nomenclature was found. Thus, an international classification of the different types of VGS to allow technical comparisons between them is highly recommended" (p. 63). This implies that the benefits and types of VGS are under research, and in need of an improved systematic lay out.

Every year, more and more articles are published on the topic of VGS, but broad reviews providing a much-needed cross-section of this field of research and systematically presenting the data and identifying the existing gaps are scarce $[21,22,24,32,33]$.

Therefore, this review paper deals with two main problems discovered during the literature review. First is the existence of many same types of VGSs, mostly living walls, with different names appearing in research studies and in manufacturers' catalogues. Looking at the manufacturer's manual is important as it reveals which research results have been translated and adopted into practice, and signals to researchers the VGS types and research areas where facilitation of further knowledge transfer is needed.

The second issue regards the under-researched benefits, especially the ones concerning social [13] and educational effects [13]. Since there is increasing interest in designing VGSs as part of a sustainable strategy for the energy optimization and environmental quality improvement factor in architecture, all benefits should be analyzed, researched, and clearly laid out. In this way, researchers could identify which benefits need further empirical research, and practicing architects and designers could have more information on which type of VGS (which supporting construction, type of soil, and type of plant), in which climate should be applied as the most appropriate sustainable design solution. 


\section{Methods}

This study adopted a scoping research review, generally used for mapping a specific research field [34]. Our research team followed the main research steps proposed by Levac et al. [34], starting by formulating our research questions. Our broad research questions initially posed were:

- What types and sub-types of green facades and living walls can be found internationally?

- What are the benefits of green facades and living walls?

- Can identified benefits be linked to a specific type or sub-type of green facade and living wall?

This was followed by identification of relevant studies, selection of studies, mapping out of data, and summarizing and reporting the results [34]. The last step, optional stakeholder consultation, was not carried out.

In order to identify relevant studies, we began with a systematic literature review based on keywords (see Table 1). We initially searched the full-text academic databases of the Web of Science, Science Research, Science Direct, as well as Google Scholar, Academia, and Research Gate to identify articles and books with empirical evidence and descriptive data. The search for academic literature provided initial results. The search was further expanded beyond academic databases, since many new and different construction types were to be found on, for example, manufacturers' websites. Therefore, the keyword search was expanded to other sources, such as manufacturers' websites and catalogs. Google, Yahoo, and Bing were the primary search engines deployed.

Table 1. Keywords that were used for initial literature review search.

\begin{tabular}{cc}
\hline Vertical Greenery Systems & Living Walls \\
\hline Green skins & Green walls \\
Vertical gardening systems & Sustainable walls \\
Vertical greening & Bio walls \\
Vertical vegetation & Vegetated facades \\
Vertical gardens & Green Facades \\
Vertical green skin & Indirect green facades \\
\cline { 2 - 2 }
\end{tabular}

The term "vertical greenery systems" as a keyword was chosen, as it is the most common name for green facades and living walls. Hence, we decided to start our search with that term. This was followed by the search with its synonyms presented in Table 1, column one. As living walls and green facades are two main types of vertical greenery systems, our next step was searching the databases with these two terms. The last step involved the database search with the synonyms of living walls and green facades.

During the first research step, we identified 13 different types of VGS presented later in the text in Table 2. When the data found on construction types was saturated, and when no new VGS construction types could be identified, the second research step began. The second research step aimed to link the 13 identified types of VGS with their benefits. Therefore, the databases were then searched with the 13 VGS construction types from Table 2 as keywords and the word 'benefits'. The second research step led to the identification of 10 VGS benefits, each presented in Tables 3-13.

Through this iterative keyword database search, in total, we have reviewed 93 sources: 73 peer-reviewed articles, 1 Ph.D. thesis, 8 books, 1 book chapter, 1 technical report, 1 guide, 2 websites, and 6 manufacturers' catalogs.

The resources examined present a compilation of studies published in different geographical locations, mostly in developed countries from 1996 to 2019.

The exclusion criteria list studies such as the ones analyzing green stepped terraces or cantilevering tree balconies, since they cannot be classified as green facades and living walls. Also, papers on traditional direct green facades were not taken into consideration, as this type does not use any 
supporting construction. The studies of thermal performances based on computer simulations that did not specify construction type were also left out. Studies commenting on technical characteristics of green facades and living walls, such as recyclability, weight and dimensions, irrigation system, and maintenance were beyond the scope of this research, though very useful data can be found in studies such as the one by Manso and Castro-Gomes [15].

\section{Analysis Strategy}

Our analysis involved three subsequent rounds. The first round of research was aimed at identifying the main types and sub-types of green facades and living walls according to their construction. The first author initially coded the studies, developing four main codes and sixteen sub-codes for VGSs, and nine codes and thirty-five subcodes for living walls. The codes presented types and subtypes of constructions. The second round of analysis sought to develop codes for green facades and living walls benefits, and in total, established 13 codes for that (Tables 3-13). The coding framework was tested and checked by the second and third authors, who performed code review. They systematically reviewed the codes by checking for inconsistencies, mistakes, and omissions after a careful reading of all studies. In this way, a consensus-coding framework was established. During the last round, the first author used the improved coding framework to code all the studies one more time. At the end of the coding, the results and interpretations were checked for incongruities; firstly, independently by all authors, and secondly, through a joint endeavor-the three authors discussed and compared individually obtained results. At the end, all authors critically examined the results and interpretations presented in the results and discussion section of this article.

\section{Results}

\subsection{Types of Construction}

VGSs are generally divided into green facades and living walls; yet, many studies could be found proposing their further classification within the green facades and living walls category. Identification of different types of VGSs and their further classification with the common name suggestion is presented in Table 2.

Table 2. Types of vertical greenery systems' (VGS) constructions.

\begin{tabular}{|c|c|c|c|c|c|}
\hline $\begin{array}{l}\text { Type of a } \\
\text { VGS }\end{array}$ & $\begin{array}{l}\text { Common } \\
\text { Name }\end{array}$ & No. & Name & $\begin{array}{l}\text { Source-Scientific } \\
\text { Journal Articles } \\
\text { and Books }\end{array}$ & $\begin{array}{c}\text { Source- } \\
\text { Manufacturer's } \\
\text { Catalog }\end{array}$ \\
\hline $\begin{array}{l}\text { GREEN } \\
\text { FACADE }\end{array}$ & $\begin{array}{l}\text { Double-skin } \\
\text { green facade }\end{array}$ & 1. & $\begin{array}{c}\text { Modular trellis panel system } \\
\text { Modular trellis } \\
\text { Double-skin green facade } \\
\text { Facade supported green wall with three-dimensional trellis }\end{array}$ & $\begin{array}{c}{[15,25]} \\
{[15,25,35]} \\
{[17,36]} \\
{[10]}\end{array}$ & \\
\hline $\begin{array}{l}\text { GREEN } \\
\text { FACADE }\end{array}$ & Grid system & 2. & $\begin{array}{c}\text { Wire-rope net systems } \\
\text { Facade supported green wall with two-dimensional treills } \\
\text { Container and/or Trellis system } \\
\text { Grid system } \\
\text { Green screen } \\
\text { Basic wall }\end{array}$ & $\begin{array}{l}{[37]} \\
{[10]} \\
{[14]} \\
{[25]}\end{array}$ & $\begin{array}{l}{[38]} \\
{[39]}\end{array}$ \\
\hline $\begin{array}{l}\text { GREEN } \\
\text { FACADE }\end{array}$ & $\begin{array}{l}\text { Cable wire } \\
\text { system }\end{array}$ & 3. & $\begin{array}{c}\text { Cable wire systems } \\
\text { Cable systems } \\
\text { Wire-rope net systems } \\
\text { Cable supported green wall }\end{array}$ & $\begin{array}{l}{[12]} \\
{[37]} \\
{[25]} \\
{[37]}\end{array}$ & \\
\hline $\begin{array}{l}\text { GREEN } \\
\text { FACADE }\end{array}$ & Mesh system & 4. & $\begin{array}{c}\text { Wire mesh system } \\
\text { Metal mesh green wall }\end{array}$ & $\begin{array}{l}{[12]} \\
{[10]}\end{array}$ & \\
\hline $\begin{array}{l}\text { LIVING } \\
\text { WALL }\end{array}$ & Pocket system & 5. & $\begin{array}{c}\text { Pocket system } \\
\text { Felt system } \\
\text { Hanging pocket living wall }\end{array}$ & $\begin{array}{l}{[12]} \\
{[14]} \\
{[10]}\end{array}$ & \\
\hline
\end{tabular}


Table 2. Cont.

\begin{tabular}{|c|c|c|c|c|c|c|}
\hline $\begin{array}{c}\text { Type of a } \\
\text { VGS }\end{array}$ & $\begin{array}{l}\text { Common } \\
\text { Name }\end{array}$ & No. & & Name & $\begin{array}{c}\text { Source-Scientific } \\
\text { Journal Articles } \\
\text { and Books }\end{array}$ & $\begin{array}{c}\text { Source- } \\
\text { Manufacturer's } \\
\text { Catalog }\end{array}$ \\
\hline \multirow{7}{*}{$\begin{array}{l}\text { LIVING } \\
\text { WALL }\end{array}$} & \multirow{7}{*}{$\begin{array}{l}\text { Geotextile } \\
\text { felt system }\end{array}$} & \multirow{7}{*}{6.} & & Hydroponic system & [12] & \\
\hline & & & & Geotextile felt system & [17] & \\
\hline & & & & Vegetated mat wall & [10] & \\
\hline & & & & Nonwoven felt system & & [40] \\
\hline & & & & $f+p$ system & & {$[40]$} \\
\hline & & & & Continuous living wall system & [15] & \\
\hline & & & & Cloth & [41] & \\
\hline \multirow{13}{*}{$\begin{array}{l}\text { LIVING } \\
\text { WALL }\end{array}$} & \multirow{5}{*}{$\begin{array}{l}\text { Modular } \\
\text { system }\end{array}$} & \multirow{5}{*}{7.} & & Modular system & [12] & \\
\hline & & & & Modular living wall & [25] & \\
\hline & & & & Panel system & {$[14,17]$} & \\
\hline & & & & Modular trays & [15] & \\
\hline & & & & tems of panels substrate containers & & [40] \\
\hline & \multirow{8}{*}{$\begin{array}{l}\text { Framed boxes } \\
\text { modular } \\
\text { living wall }\end{array}$} & & 7.1. & Modular vessels & [15] & \\
\hline & & & 7.2 & Planter tiles & [15] & \\
\hline & & & & Leaf.box system & & [40] \\
\hline & & & 7.3 . & Framed boxes modular living wall & [10] & \\
\hline & & & & Pro wall & & [39] \\
\hline & & & 7.4. & Wire cage modular living wall & [10] & \\
\hline & & & 7.5 . & Perforated boxes modular living wall & [10] & \\
\hline & & & 7.6. & Slanted cell box modular living wall & {$[10]$} & \\
\hline \multirow{3}{*}{$\begin{array}{l}\text { LIVING } \\
\text { WALL }\end{array}$} & \multirow{3}{*}{ Carrir system } & \multirow{3}{*}{8.} & & Carrir system & [12] & \\
\hline & & & & Planter box system & [42] & \\
\hline & & & & Planter boxes & [19] & \\
\hline $\begin{array}{l}\text { LIVING } \\
\text { WALL }\end{array}$ & $\begin{array}{l}\text { Substrate cell } \\
\text { systems }\end{array}$ & 9. & & Substrate cell systems & & [40] \\
\hline \multirow{2}{*}{$\begin{array}{l}\text { LIVING } \\
\text { WALL }\end{array}$} & \multirow{2}{*}{$\begin{array}{l}\text { Landscape } \\
\text { wall }\end{array}$} & \multirow{2}{*}{10.} & & Eco.bin system & & {$[40]$} \\
\hline & & & & Landscape wall & [25] & \\
\hline LIVING & \multirow{2}{*}{ Moss wall } & \multirow{2}{*}{11.} & & Moss wall & & [43] \\
\hline WALL & & & & Greenology Living Art & & [44] \\
\hline \multirow{2}{*}{$\begin{array}{l}\text { LIVING } \\
\text { WALL }\end{array}$} & \multirow{2}{*}{$\begin{array}{l}\text { Trough } \\
\text { planters }\end{array}$} & \multirow{2}{*}{12.} & & Trough planters & \multirow[t]{2}{*}{ [13] } & \\
\hline & & & & Easiwall-Pro & & [38] \\
\hline \multirow{2}{*}{$\begin{array}{l}\text { LIVING } \\
\text { WALL }\end{array}$} & \multirow{2}{*}{ Plug-in system } & \multirow{2}{*}{13.} & & Plug-in system & & [40] \\
\hline & & & & Versa wall & & [39] \\
\hline
\end{tabular}

Loh [14] lists three main categories of living walls-the panel system, felt system, and container/trellis system. Timur and Karaca [25] presented three types of living wall-landscape wall, vegetated mat wall, and modular living wall, and four types of green facades-created with flower pots or with a rewind wall: modular trellis, grid system, and wire rope net system, that are evidently different from the ones developed by Loh [14]. Additionally, Perez et al. [17] lists three types of living walls: perimeter flowerpots, panels and geotextile felt, and two types of green facades (traditional and double-skin green facade that includes modular trellises, wired, and mesh structures). Similarly, a book by Jialin [9] proposes its own division - three types of living walls (hydroponic, modular, and carrier system) and three types of green facades (cable wire, wire mesh system, and modular trellis panel system). The most recently published book in 2019 by Perez and Perini [45] divides VGS on extensive and intensive, where extensive systems are green facades, and intensive systems are living walls divided on cloth systems, modular panel systems, and active living wall systems.

Clearly, same construction types carry different names. A typical example is a hydroponic system, which is a name for a type of a living wall found in a book by Jialin [12]. Yet, there are five more different names for the same construction type, where four of them could be found in scientific articles: the geotextile felt system [17], vegetated mat wall [10,25], continuous living wall system [15], and cloth [41], and two of them could be found in named by manufacturers' catalogs: F+P system [40], and nonwoven felt system [40]. The confusion is further deepened by a variety of names for the same types of VGS constructions appearing in the manufacturer's manuals. For example, the Grid system [25] was named 'green screen' by Treebox [38], or 'basic wall' by Gsky [39]. This problem stems from 
the fact that there is a vague consensus on the names of construction types and the widely adopted division of VGSs. The problem with names in all green facades and living walls categories follows the same pattern.

There is only one consistent classification that appears in one article [29] and a book [10]. It consists of two types of green facades: a two and three-dimensional green facade system, and seven types of living walls: vegetated mat living wall system, hanging pockets living wall system, modular living wall system shaped as framed boxes, modular living wall system shaped as wire cages, modular living wall system shaped as perforated boxes, modular living wall system shaped like boxes with cells, and modular living wall system shaped as troughs.

Another problem is the lack of precise naming for a certain VGS construction system. To illustrate, many studies could be found naming one VGS construction type "hydroponic system". Yet, there are many different construction types of living walls that use the hydroponic technique. Hence, "hydroponic system" cannot be a name for a living wall, as it represents a watering technique used and not the construction type. For this reason, our classification presented in Table 2 proposes a single name-a geotextile felt system-for this type of living wall.

To ameliorate the confusion with the names of green facades and living walls, this study labelled each construction type with only one name. Table 2 in Column One clearly differentiates between green facades and living walls, in Column Two, proposes one common name for the same construction type, while in Column Four, it lists different names found in the literature with reference to the same construction type. The names were found in peer review articles and books, and are complemented by the names found in manufacturer's catalogs (see companies Gsky, Greenology, Urbanarbolismo, Treebox, Scandiamoss) to illustrate how manufacturers give specific names to their constructions. In categories where two different names exist, one found in scientific literature and another on the market, the one which is widespread in the scientific literature was adopted as a common name. An example is 'landscape wall' that was named as such in the scientific literature [25], where 'eco.bin' was a name given by manufacturers [40].

It should be noted that the constructions of green facades and living walls put in the same category in this table can have small differences in the design and materials used. For example, a living wall using a modular system can have different types of growing medium (rock wool, soil, felt, coconut fiber) where its weight determines the type of panel material.

\subsection{Benefits of VGS}

In the text that follows, the results on identified benefits of VGS will be presented. In a commentary on each benefit, empirical and descriptive data will be clearly differentiated (in the Tables 3-13, empirical studies are marked with an asterisk).

\subsubsection{Thermal Performance}

In a research paper by Wong et al. [28], they compared the thermal performance of eight types of VGSs (one type of green facade and seven types of living walls) by using the same measuring method, analyzing the VGS under the same conditions, and then comparing their performances. Such broad comparisons are rare; in the majority of cases, research studies use test rooms, computer simulations, or mathematical models to obtain empirical data. Yet, what is challenging is the fact that simulation programs are not able to consider all material characteristics, such as evapotranspiration, photosynthesis, or absorption. Since using test rooms, as the most reliable way for obtaining empirical data (test rooms can keep all the environmental parameters constant) is also the most expansive way, research studies mostly measure performances on existing facades which have already been built.

Table 3 below summarizes existing empirical research on the thermal performances of various types of green facades and living walls. It additionally shows climate regions where measurements were conducted. 
Table 3. Thermal performances.

\begin{tabular}{|c|c|c|c|}
\hline Type of Construction & $\begin{array}{c}\text { Climate } \\
\text { (Köppern Classification) }\end{array}$ & $\begin{array}{c}\text { Thermal (Heating/Cooling) } \\
\text { Performance }\end{array}$ & Source \\
\hline \multirow{11}{*}{ Double-skin green facade } & Csa & cooling performance & {$[46]^{*}$} \\
\hline & Csa & cooling performance & {$[36]^{*}$} \\
\hline & $C f a$ & cooling performance & {$[30]^{*}$} \\
\hline & BSk & cooling performance & {$[36]^{*}$} \\
\hline & Af & cooling performance & {$[47] *$} \\
\hline & $c f b$ & heating and cooling performance & {$[19]$ * } \\
\hline & $C f b$ & cooling performance & {$[48]^{*}$} \\
\hline & Af & cooling performance & {$[28]^{*}$} \\
\hline & $C f a$ & heating performance & {$[49]^{*}$} \\
\hline & Af & cooling performance & {$[50]^{*}$} \\
\hline & $C f a$ & cooling performance & {$[51]^{*}$} \\
\hline \multirow{6}{*}{ Grid system } & $C f b$ & cooling performance & {$[52]^{*}$} \\
\hline & Csb & heating and cooling performance & {$[31]^{*}$} \\
\hline & / & cooling performance & {$[53]^{*}$} \\
\hline & $C f a$ & cooling performance & {$[54]^{*}$} \\
\hline & Af & cooling performance & {$[55]^{*}$} \\
\hline & $A w$ & cooling performance & {$[56]^{*}$} \\
\hline Cable wire system & $C f a$ & cooling performance & {$[57]^{*}$} \\
\hline Mesh system & / & / & 1 \\
\hline Pocket system & Af & cooling performance & {$[42] *$} \\
\hline \multirow{5}{*}{ Geotextile felt system } & Csa & cooling performance & {$[58] *$} \\
\hline & Csa & cooling performance & {$[59] *$} \\
\hline & Csb & heating and cooling performance & {$[31]^{*}$} \\
\hline & $C f b$ & cooling performance & {$[11]^{*}$} \\
\hline & $C f a$ & cooling performance & {$[60]^{*}$} \\
\hline Modular vessels & $C f a$ & cooling performance & {$[61]^{*}$} \\
\hline Planter tiles & I & 1 & 1 \\
\hline \multirow{6}{*}{ Framed boxes modular living wall } & $C s b$ & heating and cooling performance & {$[32] *$} \\
\hline & Af & cooling performance & {$[28] *$} \\
\hline & l & cooling performance & {$[53]^{*}$} \\
\hline & $C f a$ & cooling performance & {$[62]^{*}$} \\
\hline & Csa & cooling performance & {$[63]^{*}$} \\
\hline & $C f b$ & cooling performance & {$[64] *$} \\
\hline \multirow{2}{*}{ Wire cage modular living wall } & Af & cooling performance & {$[28]^{*}$} \\
\hline & $A w$ & cooling performance & {$[65]^{*}$} \\
\hline Perforated boxes modular living wall & 1 & 1 & 1 \\
\hline Slanted cell box modular living wall & / & / & / \\
\hline Carrir system & $C f b$ & cooling performance & {$[52] *$} \\
\hline Substrate cell systems & / & / & / \\
\hline Landscape wall & / & l & / \\
\hline Moss wall & Af & cooling performance & {$[28]^{*}$} \\
\hline Trough planters & Af & cooling performance & {$[28] *$} \\
\hline Plug-in system & Af & cooling performance & {$[28]^{*}$} \\
\hline
\end{tabular}

Thermal performance, as a benefit of green facades and living walls, depends on many factors, and some of them include climate, building skin type, and density of plant coverage. Through careful incorporation of shading, insulation, and vegetation, heat can be blocked and indoor temperatures reduced by $10^{\circ} \mathrm{C}$, while vegetation as a heat buffer can reduce energy consumption for up to $20 \%$ [26]. Early experiments measuring the thermal effects of climbing plants on building facades in summer demonstrated less than $1{ }^{\circ} \mathrm{C}$ reduction in the ambient air temperature [29]. Similarly, a modular trellis panel system contributed to energy reduction by about $1 \%$ in July with maximum outside temperatures being between $37^{\circ} \mathrm{C}$ and $39^{\circ} \mathrm{C}$ [37]. Another study by Pérez et al. [46] on double-skin 
green facade in dry Mediterranean, continental conditions, conducted from April 2009 to September 2009, measured no significant differences between the outside and intermediate space, showing slightly lower temperatures in the intermediate space in the hottest months of May, June, July, and August. The indoor temperature of the facade with VGS on a sunny day was $1.7^{\circ} \mathrm{C}$, and on a cloudy day, was $1.3^{\circ} \mathrm{C}$ lower than that of the bare wall [59]. Widiastuti et al. [42] measured the temperature difference for the pocket system between the outside air temperature and interior surface vegetated facade at an average of $2.4^{\circ} \mathrm{C}$. According to Wong et al. [28], the effect on the ambient temperature of a wire cage modular living wall (in this case, the composite is peat moss) could be felt from as far as $0.60 \mathrm{~m}$ away. Reduction in the ambient temperature of up to $3.33^{\circ} \mathrm{C}$ could be observed at a distance of $0.15 \mathrm{~m}$ away.

Some of the results of thermal simulation by Stav and Lawson [66] show that yearly cooling energy savings can reach $25 \%$ with realistic design choices in subtropical environments. "Vertical garden had an efficiency much lower than that of commercial swamp coolers ( $11 \%$ vs. up to $90 \%$ ). Nevertheless, this could represent a significant reduction in the energy demands for cooling, if the garden were connected in series to a building's air conditioning system" [65] (p. 158). "Additionally, this paper has shown that air flowing behind a $3 \mathrm{~m}$ high vertical garden has a great potential to climatize a $136 \mathrm{~m}^{3}$ office space" [65] (p. 158).

The largest number of studies concluded that green facades and living walls achieve better energy performance in warm-dry climates. For example, in Madrid, total energy savings were close to $30 \%$, and in Vancouver, close to $9 \%$. The most important parameter was found to be the aspect of walls covered by vegetation. Vertical vegetation covering the walls facing North (South for the Northern hemisphere) will result in the highest energy savings [35].

\subsubsection{Reduction of Air Pollution}

Descriptive studies presented in Table 4 about the reduction of air pollution as one of the benefits of VGS suggest that they can filter pollutants from the air, and thus improve air quality in built-up areas, being both inside or outside of the building. An explanation for this is because: "plants are natural filters-taking carbon dioxide from the air and replacing it with much needed oxygen" [25] (p. 600). Additionally, the roots of the plants can remove numerous toxic chemicals from the soil, such as volatile organic compounds (VOCs), trichloroethylene (TCE), benzene, toluene, and xylene [67]; as a result, significantly lower concentrations of toxins can be found in the area near the living wall [14]. Tropical plant species are the best at removing toxins [47]. Living walls, together with green roofs, can reduce the background pollution in cities, but, parks, street trees, and intensive green roofs are more effective [27].

The capacity of VGS to reduce air pollution depends mostly on the plants used. Empirical research studies presented in Table 4, examining plants, show that the Ivy plant (Hedera helix), used only for green facades, can collect fine dust on its leaf surface significantly better than other plants, and also work as an air cleanser in rainy conditions through rain-induced leaf cleaning [5]. Empirical data from a survey on the perception of local people and employees of the VGS installed on one office building in Genoa, Italy revealed that people see VGS as effective tools to improve air quality and the urban environment [68]. Another empirical study by Viecco et al. [69] aimed to quantify the dry deposition of particle matters by vegetation species (Pitosporumtobira, Lavandulaangustifolia, Lampranthusspectabillis, Sedumalbum, and Sedumreflexum) in semiarid climates. The species with the highest potential to capture particle matter were S. album, S. reflexum, S. palmeri, and L. spectabillis. The study concluded that VGS can mitigate air pollution and should be included in decontamination plans. A study by Pugh et al. [70] showed that "increasing deposition by the planting of vegetation in street canyons can reduce street-level concentrations in those canyons by as much as $40 \%$ for $\mathrm{NO}_{2}$ and $60 \%$ for PM" (p. 1). Lastly, a study by Weerakkody et al. [71] suggests that smaller-leaved species were found to have higher PM removal potential compared to species with wider leaves. 
Table 4. Reduction of air pollution.

\begin{tabular}{|c|c|c|c|}
\hline Type of VGS & Type of Construction & Results & Source \\
\hline Living walls & NSP & $\begin{array}{l}\text { There are significantly lower concentrations of toxins in } \\
\text { the area surrounding a living wall }\end{array}$ & [25] \\
\hline Living walls & NSP & Living walls have also been shown to improve air quality & [14] \\
\hline $\begin{array}{l}\text { Green facades } \\
\text { and living walls }\end{array}$ & NSP & $\begin{array}{l}\text { VGS can contribute to cleaner air on a city scale, especially } \\
\text { if the total amount of vegetation in a city is limited due to } \\
\text { a lack of planting space }\end{array}$ & [27] \\
\hline Living wall & Geotextile felt system & $\begin{array}{l}\text { Survey-The choice "air quality improvement" was the } \\
\text { most recognized positive effect }\end{array}$ & {$[68]^{*}$} \\
\hline $\begin{array}{l}\text { Green facades } \\
\text { and living walls }\end{array}$ & NSP & $\begin{array}{l}\text { Reduced in canyon concentrations of } \mathrm{NO}_{2} \text { and } \mathrm{PM} 10 \text { by as } \\
\text { much as } 15 \% \text { and } 23 \%\end{array}$ & {$[70]^{*}$} \\
\hline Green facade & NSP & Confirms results from [70] & {$[5]^{*}$} \\
\hline $\begin{array}{l}\text { Green facades } \\
\text { and living walls }\end{array}$ & NSP & Reduced PM2.5 peak concentration up to $45.3 \%$ and $71.4 \%$ & {$[69]$ * } \\
\hline Living wall & NSP & $\begin{array}{l}\text { Smaller leaved species with a high LAI were found to have } \\
\text { a higher PM removal potential compared to species with } \\
\text { wider leaves }\end{array}$ & {$[71]^{*}$} \\
\hline
\end{tabular}

NSP: Not specified precisely; *: Empirical study.

\subsubsection{Reduction of Noise}

The descriptive studies presented in Table 5 suggest that VGS can reduce sound reflection from the hard surfaces of roads and buildings in increasingly dense cities [14] and street canyons [27]. As Timur and Karaca explain, "living walls provide a noise buffer which significantly reduces outside noise and vibration (up to $40 \mathrm{~dB}$ ) inside the building and its close area" [25] (p. 598). The degree of sound insulation depends mainly on the depth of the growing media, the type of plants, materials used for the structural components of the living wall system, and the layer of air between the plants and the wall [26]. One type of living wall, known as a landscape wall, was specially designed and described as noise intervention on Ibiza, Spain by Urbanarbolismo [40]. This living wall consists of a ceramic cell unit multiplication. Because of its weight, it can also be used for slope stabilization.

The first study from the five empirical ones which were found (Table 5) compared noise reduction benefits for seven types of living walls and one type of green facade built in HortPark in Singapore [33]. Empirical evidence from this study showed "a stronger attenuation at low to middle frequencies due to the absorbing effect of substrate while a smaller attenuation was observed at higher frequencies due to scattering from greenery" [33] (p. 419). The same study noticed an increase in the sound absorption coefficient with greater greenery coverage. A rare example of parallel comparison of the sound absorption coefficient for two different growing mediums for VGSs (hummus and coconut fiber) was conducted for three different conditions-pure growing mediums, growing mediums with plants, and with water [72]. This study found that coconut fiber, as a growing medium, showed better performance because of its granular structure, and that growing mediums with plants showed positive impacts on sound absorption. The third test showed that adding water to the structure had a bad influence on the value of the coefficient, and should not be considered insignificant. "The negative effect induced by adding water to the system can be explained by the fact that water, by filling the air pockets between the soil particles, forms a compact material which then behaves as a common narrow-band absorber" [72] (p. 3). Further empirical evidence suggests that the living wall has a weighted sound reduction index of $15 \mathrm{db}$ and weighted sound absorption coefficient of 0.40 , and concludes that living walls are significant sound insulators of buildings [73]. Perez et al. [74] concluded that a thin layer of vegetation $(20-30 \mathrm{~cm})$ in a pre-cultivated, modular-based system and double-skin green facade provides an increase of $1 \mathrm{~dB}$ in the sound insulation for traffic noise. "Greening of the upper storey's in the street and (full) facades in the courtyard itself is most efficient to achieve noise reduction" [75] (p. 34). This 
implies that VGS is most efficient when applied to acoustically hard facade materials in narrow city canons. The most recent study [76] analyzed a real living wall and two types of plants-the Hedera helix and Bergenia cassifolia, and proposed a new method for measuring the absorption properties of living walls in situ. Another paper [77] also analyzed a real living wall, and confirmed that the high values of the sound absorption coefficient were mainly due to the presence of the substrate.

Table 5. Reduction of noise.

\begin{tabular}{|c|c|c|c|}
\hline Type of VGS & Type of Construction & Results & Source \\
\hline Living walls & NSP & Living walls have also been shown to reduce noise & [14] \\
\hline Living walls & NSP & $\begin{array}{l}\text { Acoustical insulation that is far better (up to } 30 \mathrm{~dB} \text { ) } \\
\text { than that of exposed wall }\end{array}$ & [26] \\
\hline Living walls & NSP & Reduces outside noise and vibration (up to $40 \mathrm{~dB}$ ) & [25] \\
\hline Living wall & Landscape wall & Living wall used as acoustic barrier on Ibiza, Spain & [40] \\
\hline $\begin{array}{l}\text { Green facades } \\
\text { and living walls }\end{array}$ & NSP & Reduction of $2-5 \mathrm{~dB}$ & [27] \\
\hline Green facade & Double-skin green facade & $\begin{array}{l}\text { Reduction of around } 5-10 \mathrm{~dB} \text { for low to } \\
\text { middle frequency range }\end{array}$ & {$[33]^{*}$} \\
\hline Living wall & $\begin{array}{l}\text { Framed boxes } \\
\text { modular living wall }\end{array}$ & Insertion loss ranging from $2 \mathrm{~dB}$ to $3.9 \mathrm{~dB}$ & {$[33]^{*}$} \\
\hline Living wall & $\begin{array}{l}\text { Wire cage } \\
\text { modular living wall }\end{array}$ & Insertion loss ranging from $2 \mathrm{~dB}$ to $3.9 \mathrm{~dB}$ & {$[33]^{*}$} \\
\hline Living wall & Substrate cell systems & $\begin{array}{l}\text { Reduction of around } 5-10 \mathrm{~dB} \text { for low to } \\
\text { middle frequency range }\end{array}$ & {$[33]^{*}$} \\
\hline Living wall & Plug-in system & Insertion loss ranging from $2 \mathrm{~dB}$ to $3.9 \mathrm{~dB}$ & {$[33]^{*}$} \\
\hline Living wall & Pocket system & $\begin{array}{l}\text { Reduction of around } 5-10 \mathrm{~dB} \text { for low to } \\
\text { middle frequency range }\end{array}$ & {$[33]^{*}$} \\
\hline Living wall & Trough planters & Insertion loss of $8.8 \mathrm{~dB}$ & {$[33] *$} \\
\hline Living walls & NSP & $\begin{array}{l}\text { The influence of plants marked as significant in } \\
\text { ranging from } 500 \mathrm{~Hz} \text { to } 2 \mathrm{~Hz}\end{array}$ & {$[72]^{*}$} \\
\hline Living wall & $\begin{array}{l}\text { Framed boxes } \\
\text { modular living wall }\end{array}$ & $\begin{array}{l}\text { Weighted sound reduction index of } 15 \mathrm{~dB} \text { and a } \\
\text { weighted sound absorption coefficient of } 0.40\end{array}$ & {$[73]^{*}$} \\
\hline Green facade & Double-skin green facade & $\begin{array}{l}\text { Increase in the sound insulation of } 1 \mathrm{~dB} \text { for traffic } \\
\text { noise, insulation increase } 3 \mathrm{~dB} \text { for a pink noise }\end{array}$ & {$[74]^{*}$} \\
\hline Living wall & $\begin{array}{l}\text { Framed boxes } \\
\text { modular living wall }\end{array}$ & $\begin{array}{l}\text { Increase in the sound insulation of } 1 \mathrm{~dB} \text { for traffic } \\
\text { noise, insulation increase } 2 \mathrm{~dB} \text { for a pink noise }\end{array}$ & {$[74]^{*}$} \\
\hline Living wall & NSP & $\begin{array}{l}\text { The influence on the averaged road traffic noise } \\
\text { insertion loss over the courtyard stays within } 1 \mathrm{~dB}\end{array}$ & {$[75]^{*}$} \\
\hline Living wall & Trough planters & $\begin{array}{l}\text { Presence of plants with a relatively high leave area } \\
\text { density can significantly enhance the absorption } \\
\text { properties of a living wall, particularly in the } \\
\text { mediumand high frequency range, i.e. above } 1000 \mathrm{~Hz}\end{array}$ & {$[76]^{*}$} \\
\hline Living wall & Geotextile felt system & $\begin{array}{l}\text { High values of the sound absorption coefficient is } \\
\text { between } 250 \mathrm{~Hz} \text { and } 3800 \mathrm{~Hz}\end{array}$ & {$[77]^{*}$} \\
\hline
\end{tabular}

NSP: Not specified precisely; *: Empirical study.

\subsubsection{Positive Effects on Hydrology}

VGSs have a positive impact on hydrology—on the water cycle in a city, reduction of investments in the rainwater drainage system, and improvement of the local microclimate, since the VGS can absorb gradually evaporating water (Table 6). According to Loh and Stav, "as water percolates and later transpires through the living wall system, it lowers the amount as well as slows down sudden rainfall discharge to the city's storm sewers" [8] (p. 7). Some living walls use collected rainwater, 
which plays a positive and active role in urban water management. Living walls can use renewable energy sources for electricity generation (such as photovoltaic panels), which is necessary for the operation of the water pump. A drop-by-drop system can use so-called gray water or rainwater for watering the VGS plants. In addition, drainage system can be installed to collect the excess water and return it back to the system [78]. "The ability of living walls to thrive with non-potable water and the retention of significant run-off on-site offers real benefits to urban stormwater management" [14] (p. 3). A paper [13] also suggests that the vegetative surfaces can retain stormwater and water runoff from the roofs, which can help in reducing the extent of the stormwater drainage infrastructure.

Table 6. Positive effects on hydrology.

\begin{tabular}{cclc}
\hline Type of VGS & Type of Construction & Results & Source \\
\hline Green facade & Grid system & $\begin{array}{l}\text { Use collected rainwater or recycled grey-water and } \\
\text { black-water which plays a positive and active role } \\
\text { insensitive urban water management }\end{array}$ & {$[8]$} \\
\hline Living wall & NSP & $\begin{array}{l}\text { Can help a city's stormwater management through } \\
\text { the use of recycled water or the absorption of rainfall }\end{array}$ & {$[8]$} \\
\hline Living wall & $\begin{array}{l}\text { Framed boxes } \\
\text { modular living wall }\end{array}$ & $\begin{array}{l}\text { Collect the excess water and return it back to the } \\
\text { watering system of living wall }\end{array}$ & {$[78]$} \\
\hline Living wall & NSP & $\begin{array}{l}\text { Able to retain water to control the water runoff from } \\
\text { the roofs }\end{array}$ & {$[13]$} \\
\hline Living wall & Geotextile felt system & Stormwater runoff reduced by 4\% & {$[11]{ }^{*}$} \\
\hline
\end{tabular}

Only one empirical study discovered showed that green facade, together with green roof on a building in Vancouver, has the potential to reduce the stormwater runoff by $4 \%$ [11].

\subsubsection{Social Benefits}

According to Hui and Zhao [53], the social benefits of VGSs are fourfold: they offer aesthetic value in urban environment, improve human health and mental well-being, enhance public spaces, and add identity to a building (Table 7). Sheweka and Magdy suggest that "visual and physical contacts with plants can result in direct health benefits. Plants can generate restorative effects leading to decreased stress; improve patient recovery rate and higher resistance to illness" [13] (p. 596). VGS "may have a positive impact on crime reduction since residents living in 'greener' surroundings actually report lower levels of fear, fewer incivilities, and less violent behavior" [12] (p. 11).

Table 7. Social benefits.

\begin{tabular}{cclc}
\hline Type of VGS & Type of Construction & Results & Source \\
\hline $\begin{array}{c}\text { Green facades } \\
\text { and living walls }\end{array}$ & NSP & $\begin{array}{l}\text { - Aesthetic value in urban environment } \\
\text { - Improve human health and mental well-being } \\
\text { - Enhance public spaces } \\
\text { - Add identity to a building }\end{array}$ & {$[53]$} \\
\hline $\begin{array}{c}\text { Green facades } \\
\text { and living walls }\end{array}$ & NSP & $\begin{array}{l}\text { - Decrease stress } \\
\text { - Improve patient recovery rate } \\
\text { - Resistance to illness }\end{array}$ & {$[13]$} \\
\hline $\begin{array}{c}\text { Green facades } \\
\text { and living walls }\end{array}$ & NSP & $\begin{array}{l}\text { - Positive impact on crime reduction (lower levels } \\
\text { of fear, fewer incivilities, and less violent behavior) }\end{array}$ & [12] \\
\hline Living wall & Geotextile felt system & - Impact on better wellbeing of citizens & {$[68]^{*}$} \\
\hline \multicolumn{4}{c}{ NSP: Not specified precisely; * Empirical study. }
\end{tabular}

Empirical data from a survey on the perception of local people and employees of the VGS installed on one office building in Genoa, Italy revealed contradictory data, suggesting that people see VGS as 
being able to improve the urban environment and have an impact on the better wellbeing of citizens, while simultaneously believing that VGSs are "expensive and problematic" [68] (p. 906).

\subsubsection{Visual Effect}

Sutton writes about the aesthetic experience of VGS [79]. From philosophers' and social scientists' point of view, there are three categories of beauty according to which VGSs are beautiful—"unlike enjoyable or admirable beauty, ecological beauty does not attempt to control the subject with esoteric cultural knowledge or the object with precise description. Those who desire perfection in aesthetic experience will be disappointed with ecological beauty because humans will never have enough knowledge to perfectly describe or specify all-natural features, contexts, and processes" [79] (pp. 4-5).

Perini et al. [4] explains that living wall systems offer more creative potential—-thus, improved aesthetical appeal - than green walls, as the variety of climbing plants that could be used on living walls is greater. The visual effect mostly depends on the plant density used for the wall coverage. A Florawall manufacturer [80] recommends approximately 40 plants $/ \mathrm{m}^{2}$. VGSs have the possibility to be designed in different shapes when their main material is felt. Lately, new types of VGSs are appearing on the market with more design possibilities, though plant selection for them is limited. One such design is a moss wall, which uses special adhesive and sticks moos onto composite aluminum backing, which enables the creation of not only various shapes and sizes, but also 3D effects. Therefore, VGSs show great potential to be used as public art [81].

The number of empirical studies evaluating the visual effect of VGS is growing. One empirical study by Meral et al. [82] reveals how positively people evaluate living walls in a relation to their visual perception of parameters, such as diversity, aesthetic, colorfulness, complexity, applicability, worth seeing, naturalness, plant diversity, light, number of species, size, and design colorfulness. White and Gatersleben [83] showed that houses with integrated vegetation in some form are "more preferred, beautiful, restorative, and had a more positive affective quality than those without" (p. 1). Table 8 lists empirical studies [68,82-84] based on surveys, all involving passers-by. A recent study [984] with a sample size of 400 participants showed that 118 participants strongly agreed, and 185 agreed that vertical gardens were aesthetic.

Table 8. Visual effects.

\begin{tabular}{|c|c|c|c|}
\hline Type of VGS & Type of Construction & Results & Source \\
\hline $\begin{array}{l}\text { Green facades } \\
\text { and living walls }\end{array}$ & NSP & $\begin{array}{l}\text { Three categories of beauty according to which VGS are } \\
\text { beautiful: enjoyable, admirable and ecological beauty }\end{array}$ & [79] \\
\hline Living wall & NSP & $\begin{array}{l}\text { Offers much more creative and aesthetical potential } \\
\text { than green facades }\end{array}$ & {$[4]$} \\
\hline Living wall & Hydroponic system & Great potential to be used as a public art & [81] \\
\hline $\begin{array}{l}\text { Green facades } \\
\text { and living walls }\end{array}$ & NSP & $\begin{array}{l}\text { Survey-user perceive the place with VGS as beautiful, } \\
\text { special, natural, memorable, relaxing, colored, esthetic, } \\
\text { reliable, compatible, and functional }\end{array}$ & {$[82] *$} \\
\hline Living wall & Geotextile felt system & $\begin{array}{l}\text { Survey-recognized an aesthetic value as "visually } \\
\text { enhanced cityscape," but not recognized at the same level } \\
\text { the possibility of increasing the "building aesthetic" }\end{array}$ & {$[68]^{*}$} \\
\hline Living wall & NSP & $\begin{array}{l}\text { Survey-houses with integrated vegetation in some form } \\
\text { are "more preferred, beautiful, restorative, and had a more } \\
\text { positive affective quality than those without" }\end{array}$ & {$[83]^{*}$} \\
\hline Green facade & NSP & Survey-the ivy facade rated highest & {$[83]^{*}$} \\
\hline $\begin{array}{l}\text { Green facades } \\
\text { and living walls }\end{array}$ & NSP & $\begin{array}{l}\text { Survey-vertical gardens are perceived as an aesthetic } \\
\text { element in Konya city }\end{array}$ & {$[84]^{*}$} \\
\hline
\end{tabular}

NSP: Not specified precisely; *: Empirical study. 


\subsubsection{Educational Effects}

There are numerous examples of VGSs which have been built, especially in schools all around the world. For example, VGSs designed by a PhytoKinetic firm were built as a part of the "Barcelona school vertical gardens project" [85]. Living walls on schools or nature education centers can be used by students in biology or art classes [27]. However, in the scientific literature, there is almost no data about the educational benefits of VGS. Scarce data can be found in a paper by Sheweka and Magdy [13], where VGSs are explored together with green roofs (Table 9). Their authors state that "green roofs and walls are the perfect tools to teach about the environment. The next generation needs to learn about the environmental concerns of today and how we are addressing them" [13] (p. 599). They further explain that VGS can provide endless educational opportunities and can be used as tools for ecological observation, growing plants and vegetables, identifying the protection of the building. Also, the visual effect of VGSs can leave a strong impression on viewers and raise awareness about the importance of ecology [78].

Similarly, Brković [86] in her work on steps that schools can take towards environmental sustainability suggests that green roofs and VGS can contribute to the sustainability of a school architecture, and also be used as 3D teaching textbooks on sustainability [87]. She mentioned Sotteville les Rouen High School in France and the School of Art, Design, and Media at Nanyang University in Singapore as particularly inspiring examples that can illustrate good practice.

A study by McCullough et al. [88] described how an indoor living wall was integrated within a classroom learning environment and outlined an accompanying curriculum. The same study suggested that living walls: "have the potential to inspire critical thinking through a combination of project-based learning strategies and environmental education ... project-based curriculum models can connect students interactively with indoor nature and have the potential to inspire real-world thinking related to science, technology, engineering, art, and mathematics fields" [88] (p. 1).

Table 9. Educational effects.

\begin{tabular}{ccccc}
\hline Type of VGS & Type of Construction & Results & Source \\
\hline Living wall & NSP & Can be used by students in biology or art classes & {$[27]$} \\
\hline Living wall & NSP & Perfect tools to teach about the environment & {$[13]$} \\
\hline $\begin{array}{c}\text { Green facade } \\
\text { and living wall }\end{array}$ & NSP & Raise awareness about the importance of ecology & {$[78]$} & {$[87]$} \\
\hline $\begin{array}{c}\text { Green facade } \\
\text { and living wall }\end{array}$ & NSP & 3D teaching textbooks on sustainability & [88] \\
\hline Living wall & NSP & $\begin{array}{c}\text { Inspire real world thinking related to science, } \\
\text { technology, engineering, art, and mathematic fields }\end{array}$ & \\
\hline
\end{tabular}

NSP: Not specified precisely; *: Empirical study.

\subsubsection{Habitat for Urban Wildlife}

The literature suggests that VGSs can be a part of the solution to help restore wildlife habitats-the number one threat to wildlife today. Green facades and living walls can attract birds and butterflies by carefully choosing and planting attractive plant species [25]. The same article explained that many plant species are good for nesting birds, especially bushy plants, where most of them produce nectar and pollen for bees, as well as other insects, such as hoverflies, flycatchers, or moths. Plants such as the Hedera Helix is a good nesting site for robins, wrens, and hibernating butterflies. An evergreen honeysuckle, trained up a trellis, makes a good bird-roosting site. Some plant seeds are edible by birds and small mammals, and some present as food for butterflies [25]. According to Hop and Hiemstra [27], VGSs can be a hiding and nesting place, especially for insects and birds. A review by Mayrand and Clergeau [89] suggests that VGSs present a promising opportunity to enhance biodiversity in cities 
through being a part of urban wildlife corridors (Table 10). Yet, further research is needed on how they can constitute optimal vertical corridors for wildlife and reduce the isolation of green roofs, and thus contribute to landscape and urban connectivity.

One empirical study [13] conducted research on 27 green facades and the same number of bare walls in an urban environment in the city of Staffordshire, UK. The study demonstrated that a green facade colonized by climbing vegetation was used by birds, and it presented them with opportunities for nesting, food, and shelter. The study described green facades as "an effective way of providing a range of resources for birds in urban areas without the need for expensive additional land-take" [16] (p. 453). Yet, an aforementioned qualitative survey by Magliocco and Perini [68] showed that some people perceive the improvement of animal biodiversity as the worst negative effect of VGS.

Table 10. Habitat for urban wildlife.

\begin{tabular}{|c|c|c|c|}
\hline Type of VGS & Type of Construction & Results & Source \\
\hline $\begin{array}{l}\text { Green facade } \\
\text { and living wall }\end{array}$ & NSP & $\begin{array}{l}\text { Can attract birds and butterflies, bees, hoverflies, } \\
\text { flycatchers or moths, robins, wrens, } \\
\text { and hibernating butterflies }\end{array}$ & [25] \\
\hline $\begin{array}{l}\text { Green facade } \\
\text { and living wall }\end{array}$ & NSP & $\begin{array}{l}\text { Provide hiding and nesting place, especially for } \\
\text { insects and birds }\end{array}$ & [27] \\
\hline $\begin{array}{l}\text { Green facade } \\
\text { and living wall }\end{array}$ & NSP & $\begin{array}{l}\text { Promising opportunity to enhance biodiversity in } \\
\text { cities through being a part of urban wildlife corridors }\end{array}$ & [89] \\
\hline Green facade & NSP & Climbing vegetation was used by birds & {$[13] *$} \\
\hline Green facade & NSP & $\begin{array}{l}\text { The birds' activity was always restricted to the upper } \\
\text { half of the wall vegetation }\end{array}$ & {$[16]^{*}$} \\
\hline Living wall & Geotextile felt system & $\begin{array}{l}\text { Survey-among the positive effects found was the } \\
\text { creation of habitats for birds }\end{array}$ & {$[68]^{*}$} \\
\hline
\end{tabular}

NSP: Not specified precisely; *: Empirical study.

\subsubsection{Economic Benefits and Installation Costs}

Hop and Hiemstra [27] suggest that VGSs increase the value of real estate, especially if they create extra outdoor living space. A living wall is a unique way to add more greenery to your 'interior scape' design or exterior landscaping plan, and attracts more people interested in purchasing your property [9]. According to the same website, having plants in and around a building can increase real estate value by up to $20 \%$. Data provided by Jialin [12] shows different percentages, suggesting that living walls have the potential to increase residential and commercial property values by 7 to $15 \%$.

Empirical studies presented in Table 11 show that the economic benefits of VGS differs across the world. A scientific paper by Veisten et al. [90] assessed the market possibilities in Toronto, where vegetation measures would yield property increase for $6-15 \%$, with a midpoint of $10.5 \%$. "A cost-benefit analysis of the green wall case indicates that this measure is economically promising when valuing the noise attenuation in the quieter area and adding the amenity/aesthetic value of the green wall" [90] (p. 3770). Cost analysis by Meral et al. [82] confirms that living walls are the most expensive type of man-made VGS. "Considering the costs of two wall systems, it was observed that a green facade could be established with about 12.01 of the cost of living walls" [82] (p. 14). A cost-benefit analysis of the living walls showed that "they have a longer payback period of 17 years considering the local unsubsidized electricity rates in UAE" [91] (p. 8).

Another economic benefit of VGS is tax incentives. A paper by Perini and Rosasco [92] states that "economic incentives (tax reduction) could reduce personal initial cost allowing a wider diffusion of greening systems to reduce environmental issues in dense urban areas, such as urban heat island phenomenon and air pollution" [92] (p. 110). 
Table 11. Economic benefits.

\begin{tabular}{|c|c|c|c|}
\hline Type of VGS & Type of Construction & Results & Source \\
\hline $\begin{array}{l}\text { Green facade } \\
\text { and living wall }\end{array}$ & NSP & $\begin{array}{l}\text { Increase the value of real estate, especially if they } \\
\text { create extra outdoor living space }\end{array}$ & [27] \\
\hline $\begin{array}{l}\text { Green facade } \\
\text { and living wall }\end{array}$ & NSP & Increase real estate value by up to $20 \%$ & [9] \\
\hline Living wall & NSP & $\begin{array}{l}\text { Increase residential and commercial property } \\
\text { values by } 7 \% \text { to } 15 \%\end{array}$ & [12] \\
\hline Living wall & Geotextile felt system & $\begin{array}{l}\text { Size of the unit value for green walls does have a } \\
\text { clear impact on the estimated cost efficiency }\end{array}$ & {$[90] *$} \\
\hline Green facade & Mesh system & $\begin{array}{l}\text { Economically sustainable - payback period } \\
\text { of } 16 \text { years }\end{array}$ & {$[91]$ * } \\
\hline Living wall & Geotextile felt system & Cannot be considered economically sustainable & {$[91]^{*}$} \\
\hline Living wall & Carrir system & Payback period of 17 years & {$[91]^{*}$} \\
\hline
\end{tabular}

According to Perini et al. [19], VGS improves the visual, aesthetic, and social aspects of the urban area, which have a high influence on the economic value of a building and neighborhood. This study, published in 2011, explains that it is possible to compare costs needed for the installation of green facades and living wall systems available on market in Europe, and they depend on installation equipment, the height of a building, location, connections, and so forth. The cheapest are green facades, and their purchase and installation cost was, at the time, less than $75 € / \mathrm{m}^{2}$ [19]. A review from the year 2015 by Manso and Castro-Gomes explains that "these systems have a small environmental burden considering that they have no materials involved and have low maintenance needs" [15] (p. 869). The most-used hydroponic system costs $350-750 € / \mathrm{m}^{2}$ [19] (Table 12). On the contrary, living walls cost more as they require nutrients and different watering system materials, which makes their design more complex. Another paper [77] compared the price for a living wall with a geotextile felt system on the market $\left(750 € / \mathrm{m}^{2}\right)$ with the price of same system experimentally made of recycled materials $\left(400 € / \mathrm{m}^{2}\right)$.

Table 12. Installation costs.

\begin{tabular}{ccccc}
\hline \multirow{2}{*}{ Type of VGS } & \multirow{2}{*}{ Type of Construction } & \multicolumn{2}{c}{ Results } & \multirow{2}{*}{ Source } \\
\cline { 3 - 4 } & & Location & Price & \\
\hline Green facade & Grid system & Europe & $40-75 € / \mathrm{m}^{2}$ & {$[19]$} \\
Living wall & Trough planters & Europe & $400-600 € / \mathrm{m}^{2}$ & {$[19]$} \\
Living wall & Framed boxes modular living wall & Europe & $750-1200 € / \mathrm{m}^{2}$ & {$[19]$} \\
Living wall & Geotextile felt system & Europe & $350-750 € / \mathrm{m}^{2}$ & {$[19]$} \\
Living wall & Carrir system & Dubai & $288 \mathrm{US} \$ / \mathrm{m}^{2}$ & {$[91]$} \\
Green facade & Cable wire & Turkey & $34.87 € / \mathrm{m}^{2}$ & {$[82]$} \\
Living wall & Geotextile felt system & Turkey & $415.649 € / \mathrm{m}^{2}$ & {$[82]$} \\
Living wall & Geotextile felt system & Turin, Italy & $400 € / \mathrm{m}^{2}$ & {$[77]$} \\
\hline
\end{tabular}

NSP: Not specified precisely; *: Empirical study.

\subsubsection{Facade Existence}

Descriptive data presented in Table 13 suggests that external VGSs can have a significant influence on facade existence. VGSs serve as an additional external layer that can save the facade from many physical environmental influences. Their usage can reduce climatic stress on building facades, prolong the life of buildings, and reduce cost for the painting materials [93]. Haggag [26] states that VGS can indeed prolong the life of existing facades if waterproof panels are used and separated a layer by air, as this can protect a building from wind, solar radiation, and rain, can allow moisture to escape, and can 
also contribute to the reduction of expansion and contraction of building materials. Wong et al. adds to this discussion and explains that: "by limiting the diurnal fluctuation of wall surface temperatures, the lifespan of building facades is prolonged, slowing down wear and tear as well as savings in maintenance cost and the replacement of facade parts" [28] (p. 663).

Table 13. Facade existence.

\begin{tabular}{cclc}
\hline Type of VGS & Type of Construction & Results & Source \\
\hline $\begin{array}{c}\text { Green facade } \\
\text { and living wall }\end{array}$ & NSP & $\begin{array}{l}\text { Can reduce climatic stress on building facades and } \\
\text { prolong the life of buildings }\end{array}$ & [93] \\
\hline $\begin{array}{c}\text { Green facade } \\
\text { and living wall }\end{array}$ & NSP & $\begin{array}{l}\text { Can prolong the life of existing facades if waterproof } \\
\text { panels are used and separated a layer by air }\end{array}$ & [26] \\
\hline $\begin{array}{c}\text { Green facade } \\
\text { and living wall }\end{array}$ & NSP & $\begin{array}{l}\text { By limiting the diurnal fluctuation of wall surface } \\
\text { temperatures, the lifespan of building facade is prolonged }\end{array}$ & {$[28]$} \\
\hline \multicolumn{5}{c}{ NSP: Not specified precisely; *: Empirical study. }
\end{tabular}

\section{Discussion}

This study suggests that one of the main challenges within the academic discussion on VGS is the use of various names for the same types of VGS constructions. Some studies use names of VGS not found in other research papers. The confusion is deepened further by the names given by manufacturers. This evidently makes it difficult to follow the train of thought within the field, and thus hinders the progress of research on this topic and makes contributions to it challenging.

The need for an improved VGS nomenclature and classification system is evident. This study proposes the creation of an acronym generation system that is available online. For example, on a drop-down menu, a type of construction and its material, irrigation system, planting media, and plant species could be selected, which will result in an acronym being created in the last field (Table 14). Further discussion on the creation and use of such a system requires additional multidisciplinary research, including architects, urban planners, landscape architects, biologists, and other relevant professionals so that an elaborate list of all categories is created, and it can be decided who should be maintaining such a system, as well as whether and how individuals could add new categories to it. All these goals surpass the aims of this review study and should be tackled in the future.

Table 14. An illustrative example of acronym creation for an improved VGS nomenclature system.

\begin{tabular}{ccccccc}
\hline VGS Type & $\begin{array}{c}\text { Construction } \\
\text { System }\end{array}$ & $\begin{array}{c}\text { Construction } \\
\text { System Material }\end{array}$ & $\begin{array}{c}\text { Irrigation } \\
\text { System }\end{array}$ & Planting Media & $\begin{array}{c}\text { Plant } \\
\text { Species }\end{array}$ & Acronym \\
\hline Green facade & Grid & Plastic & Self-irrigated & Soil & Hedera helix & GF.G.P.S-i.S.HH. \\
\hline Living wall & Felt pocket & Tough fiber & Automatic drip & Soil in moist felt & Mentha & LW.FP.Tf.Ad.SMf.M. \\
\hline
\end{tabular}

Secondly, benefits for different types of green facades and living walls are not clearly laid out, and the researched benefits are not always supported by empirical evidence. Sometimes there is no scientific research about specific benefits for particular types of VGS constructions, and we at times lack an appropriate measurement tool. In the practitioners' arena, a more intense application and further testing in the practice of green facades and living walls are potentially hampered.

Based on all the analyzed papers shown in Table 3, it can be concluded that thermal performance, as a benefit of VGS, is the most broadly explored one; yet there is still room for further research. The challenge is that different types of VGS were explored in different climate regions using different tools, so the results obtained are not directly comparable for various types of VGS. Experiments conducted in the real-life environment of already-built buildings have VGS as their part, or have it installed on just one part of the building's surface-usually just one wall, so the full potential and full effect on the whole building cannot be estimated. Additionally, some empirical studies do not contain a complete description of the VGS analyzed or measurement tools used. 
What is more, qualitative studies exploring human perception of the thermal performance of VGS are exceptionally rare. As it is known that measured and perceived temperatures are not the same, post-occupancy evaluations with building occupants should be carried out so that the extent to which VGS can contribute to the thermal comfort of people in and outside of the buildings can be determined.

Improving air quality is another benefit of VGS that is not being fully empirically explored. Although using VGS as an air-cleansing attempt exists in many European cities, there is no research data to unequivocally confirm the ability of VGS to purify the air and contribute to air quality. There are scant examples of research studies examining the ability of specific plant species to capture dust, clean air, or remove toxins from soil. This signals that more studies are needed which compare how various types of VGS constructions (consisting of different supporting constructions, soil types, and plant species) could contribute to improvements in air quality, and suggest which VGS types serve this purpose best in which environment and climate region.

A similar problem can be observed in relation to empirical studies measuring the reduction of noise and positive effects on the hydrology of VGS. The largest majority of information is descriptive, and mostly written as an assumption based on the similarities with green roofs.

It is very good that the number of empirical studies evaluating the visual effects of VGS is constantly growing; however, more research is needed on how different VGS design elements, such as the type of plant, color, smell, height, position on the wall, and tactile experience are perceived by other people so that occupants' preferences can be discovered, and the suitability of different types of VGS for different types of buildings can also be explained.

The least-explored benefits are certainly the social and educational benefits of VGS. Health improvement and crime reduction as social benefits of VGS have been explored, to some extent. However, more studies are needed on how VGS can contribute to other social benefits, such as the creation of a sense of community. Although there are a lot of VGS projects in schools, only one study describing VGS as 3D textbooks supporting sustainability literacy in children could be found [87]. Additionally, a study by Magliocco and Perini [68] particularly emphasizes the importance of educating citizens, by stating that "knowledge of the benefits of technology solutions contributes to their [peoples'] favorable perceptions, however, ... research shows that communicating the (possible) positive effects of green facades to citizens is needed and adding that "that awareness has to be increased to make sure citizens understand the environmental benefits of vegetation as well as the aesthetic aspects" [68] (p. 906). Therefore, assessment of the pedagogical potential of VGS is a fruitful avenue for future research.

VGS presents itself as a suitable habitat for insects and birds. Empirical evidence suggests that VGS can present birds with opportunities for nesting, food, and shelter, and it can also be suitable spaces for the growth of indigenous plant species and edible plants. Their selection depends on the local climate conditions. Papers discussing plant selection-a key component for the successful existence of living walls-do not include edible plants. With an ever-pressing shortage of farming soil within and in the proximity of urban areas, further studies should explore the potential of VGS to be used for producing edible plants and herbs. Additionally, more research is needed on how VGS, together with green roofs, can form an integral part of urban wildlife corridors and improve landscape connectivity.

Although it is not the remit of this paper to discuss in-depth future research endeavors of this group of researchers, we believed it is important to signal the future direction of our research relevant to this topic. As an ever-growing number of VGS is being built in schools across the world-usually as part of school gardens-we are embarking on a piece of research to empirically evaluate the educational potential of VGS as a pedagogical tool (particularly able to inspire learning on important sustainability topics) and develop an appropriate participatory evaluation tool for doing so in order to include teachers and pupils, who are the most important target audience and the main users of VGS in schools.

\section{Conclusions}

This review paper showed that the research on VGS is a constantly progressing field. The number of research studies reviewed provides a good overview of the VGS systems available, as well as some 
of the benefits; yet, room for improvement exists. A central classification and nomenclature system (preferably available online) should be established. The system should prove to be useful for researchers and manufacturers alike in providing precise naming of the VGS. The precise naming of VGS, and exact descriptions of measurement tools and of the climate region should be strongly encouraged by journal editors where studies on VGS are published to enable more precise cross-comparisons between studies. Much further empirical evidence is needed so that greater claims of VGS efficiency and cost-effectiveness could be made. Additional studies exploring large wall sizes over a prolonged period could reveal the effects of VGS on the whole building. Qualitative post-occupancy studies are particularly deficient. There is an evident need for research including occupants' buildings with VGS, and not just passers-by, exploring their understanding and knowledge of the importance of VGS systems, together with occupants' satisfaction with building comfort. Quantitative and in-depth qualitative exploitations of further social, visual, and educational benefits are necessary.

Author Contributions: Conceptualization of this project was carried out by the M.R. and M.B.D., the search for resources and visualization by the M.R., while methodology, analysis and writing by all three authors.

Funding: This project was carried out as a part of the first author's pre-doctoral one-year research project hosted at TU Munich, Faculty for Architecture, Chair of Building Technology and Climate Responsive Design, and supervised by Marta Brković Dodig and Thomas Auer. The research was funded through Deutsche Bundesstiftung Umwelt (German Federal Environmental Foundation) MOE exchange scholarship awarded to the first author. The work of the second author was supported through Open Society Foundation-Civil Society Scholar Award grant IN2015-22293.

Conflicts of Interest: The authors declare no conflict of interest.

\section{References}

1. Hopkins, G.; Goodwin, C. Living Architecture: Green Roofs and Walls, 1st ed.; CSIRO Publishing: Melbourne, Australia, 2011; ISBN 9780643103078.

2. Blanc, P. The Vertical Garden: From Nature to the City, 1st ed.; W. W. Norton Company: New York, NY, USA, 2008; ISBN1 -13 978-0393733792. ISBN2 -10 0393733793.

3. Uffelen, C.V. Facade Greenery: Contemporary Landscaping, 1st ed.; Braun: Englewood, CO, USA, 2011; ISBN 978-3-03768-075-9.

4. Perini, K.; Ottelé, M. Designing Green Facades and Living Wall Systems for Sustainable Constructions. Int. J. Des. Nat. Ecodyn. 2014, 9, 31-46. [CrossRef]

5. Reznik, G.; Schmidt, E. Reduction of Emissions by Vegetation—Dry Collection and Wet Resuspension of Fine Dust Particles on Ivy. GRdL 2009, 69, 434-438.

6. Stec, W.J.; van Paassen, A.H.C.; Maziarz, A. Modelling the Double Skin Facade with Plants. Energy Build. 2005, 37, 419-427. [CrossRef]

7. Dunnet, N.; Kingsburry, N. Planting Green Roofs and Living Walls, 1st ed.; Timber Press: Portland, OR, USA, 2008; ISBN1 -13 9780881929119. ISBN2 -10 0881929115.

8. Loh, S.; Stav, Y. Green a City Grow a Wall. In Proceedings of the Subtropical Cities 2008 Conference: From Fault-lines to Sight-lines: Subtropical Urbanism in 20-20, Brisbane, Australia, 3-6 September 2008; pp. 1-10.

9. Green over Gray. Available online: http://www.greenovergrey.com/ (accessed on 30 December 2018).

10. Wood, A.; Bahrami, P.; Safarik, D. Green Walls in High Rise Building, 1st ed.; Images Publishing: Chicago, IL, USA, 2014; ISBN 9781864705935.

11. Roehr, D.; Laurenz, J. Living Skins: Environmental Benefits of Green Envelopes in the City Context. WIT Trans. Ecol. Environ. 2008, 113, 149-158. [CrossRef]

12. Jialin, T. Living Wall: Jungle to Concrete, 1st ed.; Design Media Publishing Limited: Hong Kong, China, 2013; ISBN 9789881545107.

13. Sheweka, S.; Magdy, N. The Living Walls as an Approach for a Healthy Urban Environment. Energy Procedia 2011, 6, 592-599. [CrossRef]

14. Loh, S. Living Walls-A Way to Green the Built Environment. In Environment Design Guide; Australian Institute of Architects: Brisbane, Australia, 2008; pp. 1-7.

15. Manso, M.; Castro-Gomes, J. Green Wall Systems: A Review of their Characteristics. Renew. Sustain. Energy Rev. 2015, 41, 863-871. [CrossRef] 
16. Chiquet, C.; Dover, J.V.; Mitchell, P. Birds and the Urban Environment: The Value of Green Walls. Urban Ecosyst. 2013, 16, 453-462. [CrossRef]

17. Pérez, G.; Coma, J.; Martorell, I.; Cabeza, L.F. Vertical Greenery Systems (VGS) for Energy Saving in Buildings: A Review. Renew. Sustain. Energy Rev. 2014, 39, 139-165. [CrossRef]

18. Hunter, A.M.; Williams, N.S.G.; Rayner, J.P.; Aye, L.; Hes, D.; Livesley, S.J. Quantifying the Thermal Performance of Green Facades: A Critical Review. Ecol. Eng. 2014, 63, 102-113. [CrossRef]

19. Perini, K.; Ottelé, M.; Haas, E.M.; Raiteri, R. Greening the Building Envelope, Facade Greening and Living Wall Systems. Open J. Ecol. 2011, 1, 1-8. [CrossRef]

20. Bustami, R.A.; Belusko, M.; Ward, J.; Beecham, S. Vertical Greenery Systems: A Systematic Review of Research Trends. Build. Environ. 2018, 146, 226-237. [CrossRef]

21. Susorova, I.; Bahrami, P. Facade-Integrated Vegetation as an Environmental Sustainable Solution for Energy-Efficient Buildings; MADE Research Journal of Cardiff University: Cardiff, UK, 2013; pp. 6-14.

22. Koc, C.B.; Osmond, P.; Peters, A. Towards a Comprehensive Green Infrastructure Typology: A Systematic Review of Classification Approaches, Methods and Typologies. Urban Ecosyst. 2017, 20, 15-35. [CrossRef]

23. Medl, A.; Stangl, R.; Florineth, F. Vertical Greening Systems-A Review on Recent Technologies and Research Advancement. Build. Environ. 2017, 125, 227-239. [CrossRef]

24. Radosavljevic, J.; Vukadinovic, A.; Vasovic, D.; Petkovic, A. Attenuation of Road Traffic Noise by Vegetation in Urban Spaces. An. Univ. "Eftimie Murgu" Reşiţa Anul XXII 2015, 2, 318-326.

25. Timur, Ö.B.; Karaca, E. Vertical Gardens (CHAPTER 22). In Advances in Landscape Architecture, 1st ed.; Ozyavuz, M., Ed.; IntechOpen: London, UK, 2013; pp. 587-622. [CrossRef]

26. Haggag, M.A. The Use of Green Walls in Sustainable Urban Context: With Reference to Dubai, UAE. WIT Trans. Ecol. Environ. 2010, 128, 261-270. [CrossRef]

27. Hop, M.; Hiemstra, J.A. Contribution of Green Roofs and Walls to Ecosystem Services of Urban Green. Acta Hortic. 2012, 990, 475-480. [CrossRef]

28. Wong, N.H.; Tan, A.Y.K.; Chen, Y.; Sekar, K.; Tan, P.Y.; Chan, D.; Chiang, K.; Wong, N.C. Thermal Evaluation of Vertical Greenery Systems for Building Walls. Build. Environ. 2010, 45, 663-672. [CrossRef]

29. Susorova, I.; Angulo, M.; Bahrami, P.; Stephens, B. A Model of Vegetated Exterior Facades for Evaluation of Wall Thermal Performance. Build. Environ. 2013, 67, 1-13. [CrossRef]

30. Euán, L.A.C.; Amador, A.G.; De la Torre, J.M.O. Thermal Performance of Two Vertical Greenery Systems in Warm-Sub-Humid Climate. In Proceedings of the PLEA 2013-29th Conference, Sustainable Architecture for a Renewable Future, Munich, Germany, 10-12 September 2013; Available online: https://mediatum.ub.tum. de/doc/1169563/1169563.pdf (accessed on 25 July 2019).

31. Ottelé, M.; Perini, K.; Fraaij, A.L.A.; Haas, E.M.; Raiteri, R. Comparative Life Cycle Analysis for Green Facades and Living Wall Systems. Energy Build. 2011, 43, 419-3429. [CrossRef]

32. Coma Arpón, J. Green Roofs and Vertical Greenery Systems as Passive Tools for Energy Efficiency in Buildings. Ph.D. Thesis, University of Lleida, Spain 2016. Available online: https://www.tdx.cat/handle/10803/399726 (accessed on 25 July 2019).

33. Wong, N.H.; Tan, A.Y.K.; Tan, P.Y.; Chiang, K.; Wong, N.C. Acoustics Evaluation of Vertical Greenery Systems for Building Walls. Build. Environ. 2010, 45, 411-420. [CrossRef]

34. Levac, D.; Colquhoun, H.; O’Brien, K. Scoping Studies: Advancing the Methodology. Implement. Sci. 2010, 5-69. [CrossRef] [PubMed]

35. Laurenz, J.; Paricio, I.; Alvarez, J.; Ruiz, F. Natural Envelope. The Green Element as a Boundary Limit. In Proceedings of the 2005 World Sustainable Building Conference, Tokyo, Japan, 27-29 September 2005; pp. 4653-4660.

36. Coma, J.; Pérez, G.; Solé, C.; Castell, A.; Cabeza, L.F. New Green Facades as Passive Systems for Energy Savings on Buildings. Energy Procedia 2014, 57, 1851-1859. [CrossRef]

37. Kontoleon, K.J.; Eumorfopoulou, E.A. The Effect of the Orientation and Proportion of a Plant-Covered Wall Layer on the Thermal Performance of a Building Zone. Build. Environ. 2010, 45, 1287-1303. [CrossRef]

38. Treebox. Available online: http://www.treebox.co.uk/products/easiwall-green-wall.html (accessed on 30 December 2018).

39. Gsky. Available online: http://gsky.com/ (accessed on 30 December 2018).

40. Urbanarbolismo. Available online: http:/www.urbanarbolismo.es/blog/fachadas-vegetales-urbanarbolismo/ \#fieltro (accessed on 30 December 2018). 
41. Pérez-Urrestarazu, L.; Fernández-Cañero, R.; Franco-Salas, A.; Egea, G. Vertical Greening Systems and Sustainable Cities. J. Urban Technol. 2016, 22, 65-68. [CrossRef]

42. Widiastuti, R.; Prianto, E.; Budi, W.S. Performance Evaluation of Vertical Gardens. Int. J. Arch. Eng. Const. 2016, 5, 13-20. [CrossRef]

43. Scandiamoss. Available online: http://scandiamoss.com/ (accessed on 30 December 2018).

44. Greenology. Available online: http://greenology.sg/products/greenology-vertivegies/ (accessed on 30 December 2018).

45. Perez, G.; Perini, K. Nature Based Strategies for Urban and Building Sustainability, 1st ed.; Butterworth-Heinemann: Oxford, UK, 2018; eBook ISBN 9780128123249, Paperback ISBN: 9780128121504.

46. Pérez, G.; Rincón, L.; Vila, A.; González, J.M.; Cabeza, L.F. Green Vertical Systems for Buildings as Passive Systems for Energy Savings. Appl. Energy 2011, 88, 4854-4859. [CrossRef]

47. Larsen, S.F.; Filippín, C.; Lesino, G. Thermal Simulation of a Double Skin Facade with Plants. Energy Procedia 2014, 75, 1763-1772. [CrossRef]

48. Ip, K.; Lam, M.; Miller, A. Shading Performance of a Vertical Deciduous Climbing Plant Canopy. Build. Environ. 2010, 81-88. [CrossRef]

49. Xing, Q.; Hao, X.; Lin, Y.; Tan, H.; Yang, K. Experimental Investigation on the Thermal Performance of a Vertical Greening System with Green Roof in Wet and Cold Climates during Winter. Energy Build. 2019, 183, 105-117. [CrossRef]

50. Sulaiman, M.K.A.M.; Jamil, M.; Kuttler, W.; Shahidan, M.F. Shading Performance of Tropical Climbing Plant: Anemopaegma chamberlaynii on Green Façade. In Proceedings of the International Sustainable Tropical Environmental Design Conference, Serdang, Malaysia, 18-19 December 2013.

51. Feng, Y.; Feng, Y.; Feng, Q.; Zhi, Z.; Jiawei, Y. Summertime Thermal and Energy Performance of a Double-Skin Green Facade: A Case Study in Shanghai. Sustain. Cities Soc. 2018, 39, 43-51. [CrossRef]

52. Alexandri, E.; Jones, P. Temperature Decrease in an Urban Canyon due to Green Walls and Green Roofs in Diverse Climates. Build. Environ. 2008, 43, 480-493. [CrossRef]

53. Hui, S.C.M.; Zhao, Z. Thermal Regulation Performance of Green Living Walls in Buildings. In Proceedings of the Joint Symposium 2013: Innovation and Technology for Built Environment, Hong Kong, China, 12 November 2013.

54. Koyama, T.; Yoshinaga, M.; Maeda, K.-I.; Yamauchi, A. Transpiration Cooling Effect of Climber Greenwall with an Air Gap on Indoor Thermal Environment. Ecol. Eng. 2015, 83, 343-353. [CrossRef]

55. Rahman, A.M.A.; Yeok, F.S.; Amir, A.F. The Building Thermal Performance and Carbon Sequestration Evaluation for Psophocarpus tetrogonobulus on Biofacade Wall in the Tropical Environment. World Acad. Sci. Eng. Technol. 2011, 5, 206-214.

56. Sunakorn, P.; Chanikarn Yimprayoon, C. Thermal Performance of Biofacade with Natural Ventilation in the Tropical Climate. Procedia Eng. 2011, 21, 34-41. [CrossRef]

57. Koyama, T.; Yoshinaga, M.; Maeda, K.-I.; Yamauchi, A. Identification of Key Plant Traits Contributing to the Cooling Effects of Green Facades Using Freestanding Walls. Build. Environ. 2013, 66, 96-103. [CrossRef]

58. Nori, C.; Olivieri, F.; Grifoni, R.C.; Bedoya, C. Testing the Performance of a Green Wall System on an Experimental Building in the Summer. In Proceedings of the 29th Conference, Sustainable Architecture for a Renewable Future, Munich, Germany, 10-12 September 2013; pp. 215-230.

59. Mazzali, U.; Peron, F.; Scarpa, M. Thermo-Physical Performances of Living Walls via Field Measurements and Numerical Analysis. WIT Trans. Built. Environ. 2012, 4, 251-259. [CrossRef]

60. Perini, K.; Bazzocchi, F. Field Monitoring in Mediterranean Climate to Quantify Thermal Performances of Vertical Greening Systems. Powerskin Conf. Proc. 2017, 113-122. [CrossRef]

61. Jim, C.Y.; He, H. Estimating Heat Flux Transmission of Vertical Greenery Ecosystem. Ecol. Eng. 2011, 37, 1112-1122. [CrossRef]

62. Chen, Q.; Li, B.; Liu, X. An Experimental Evaluation of the Living Wall System in Hot and Humid Climate. Energy Build. 2013, 61, 298-307. [CrossRef]

63. Cheng, C.Y.; Cheung KK, S.; Chu, L.M. Thermal Performance of a Vegetated Cladding System on Facade Walls. Build. Environ. 2010, 45, 1779-1787. [CrossRef]

64. Maricruz, S.J. Green walls: A Sustainable Approach to Climate Change, a Case Study of London. Archit. Sci. Rev. 2018, 61, 48-57. [CrossRef] 
65. Davis, M.J.M.; Ramírez, F.; Vallejo, A.L. Vertical Gardens as Swamp Coolers. Procedia Eng. 2015, 118, $145-159$. [CrossRef]

66. Stav, Y.; Lawson, G. Vertical Vegetation Design Decisions and their Impact on Energy Consumption in Subtropical Cities. WIT Trans. Ecol. Envir. 2012, 1, 489-550. [CrossRef]

67. Wolverton, B.C.; Douglas, W.L.; Bounds, K. Interior Landscape Plants for Indoor Air Pollution Abatement; Final Technical Report; NASA-TM-101766; NASA: Hancock County, MS, USA, 1989.

68. Magliocco, A.; Perini, K. The Perception of Green Integrated into Architecture: Installation of a Green Facade in Genoa, Italy. Environ. Sci. 2015, 2, 899-909. [CrossRef]

69. Viecco, M.; Vera, S.; Jorquera, H.; Bustamante, W.; Gironas, J.; Dobbs, C.; Leiva, E. Potential of Particle Matter Dry Deposition on Green Roofs and Living Walls Vegetation for Mitigating Urban Atmospheric Pollution in Semiarid Climates. Sustainability 2018, 10, 2431. [CrossRef]

70. Pugh, T.A.M.; MacKenzie, A.R.; Whyatt, J.D.; Hewitt, C.N. The Effectiveness of Green Infrastructure for Improvement of Air Quality in Urban Street Canyons. Environ. Sci. Technol. 2012, 46, 7692-7699. [CrossRef] [PubMed]

71. Weerakkody, U.; Dover, J.W.; Mitchell, P.; Reiling, K. Particulate Matter Pollution Capture by Leaves of Seventeen Living Wall Species with Special Reference to Rail-Traffic at a Metropolitan Station. Urban For. Urban Gree. 2017. [CrossRef]

72. Bratičević, J.; Ristanović, I.; Drinčić, D. Apsorpciona Svojstva Različitih Tipova Zemljišta i Mogućnost Primene u Tehnologiji Vertikalnih Vrtova. In Proceedings of the ETRAN 2016-60th Conference, Zlatibor, Serbia, 13-16 June 2016; pp. 1-4, ISBN 978-86-7466-618-0.

73. Azkorra, Z.; Pérez, G.; Coma, J.; Cabeza, L.F.; Bures, S.; Álvaro, J.E.; Erkoreka, A.; Urrestarazu, M. Evaluation of Green Walls as a Passive Acoustic Insulation System for Buildings. Appl. Acoust. 2015, 89, 46-56. [CrossRef]

74. Pérez, G.; Coma, J.; Barreneche, C.; Gracia, A.; Urrestarazu, M.; Burés, S.; Cabeza, L.F. Acoustic Insulation Capacity of Vertical Greenery Systems for Buildings. Appl. Acoust. 2016, 110, 218-226. [CrossRef]

75. Renterghem, T.V.; Hornikx, M.; Forssen, J.; Botteldooren, D. The Potential of Building Envelope Greening to Achieve Quietness. Build. Environ. 2013, 61, 34-44. [CrossRef]

76. Romanova, A.; Horoshenkov, K.V.; Hurrell, A. An Application of a Parametric Transducer to Measure Acoustic Absorption of a Living Green Wall. Appl. Acoust. 2019, 145, 89-97. [CrossRef]

77. Serra, V.; Bianco, L.; Candelari, E.; Giordano, R.; Montacchini, E.; Tedesco, S.; Larcher, F.; Schiavi, A. A Novel Vertical Greenery Module System for Building Envelopes: The Results and Outcomes of a Multidisciplinary Research Project. Eng. Build. 2017, 146, 333-352. [CrossRef]

78. Radić, M.; Arsić, J.; Džaleta, M.; Stevović, S. Eco-Architecture and Sustainable Design as a Function of the Quality of Environment. In Sustainable Buildings and Urban Oasis, Proceedings of International Green Build Conference 2011, 4-7 October 2011; Ecoist: Belgrade, Serbia, 2012; pp. 109-113.

79. Sutton, R. Aesthetics for Green Roofs and Green Walls. J. Living Archit. 2014, 2, 1-20.

80. Florawall. Available online: http://www.florawall.at/ (accessed on 30 December 2018).

81. Bakar, N.I.A.A.; Mansor, M.; Harun, N.Z. Vertical Greenery System as Public Art? Possibilities and Challenges in Malaysian Urban Context. Procedia Soc. Behv. 2014, 153, 230-241. [CrossRef]

82. Meral, A.; Başaran, N.; Yalcınalp, E.; Doğan, E.; Ak, M.K.; Eroğlu, E. A Comparative Approach to Artificial and Natural Green Walls According to Ecological Sustainability. Sustainability 2018, 10, 1995. [CrossRef]

83. White, E.; Gatersleben, B. Greenery on Residential Buildings: Does it Affect Preferences and Perceptions of Beauty? J. Environ. Psychol. 2011, 31, 89-98. [CrossRef]

84. Qasim, S.A.O.; Güngör, S. Investigating the Vertical Garden Applications in Konya City, Turkey: A Case Study. Arch. Agric. Environ. Sci. 2019, 4, 63-68. [CrossRef]

85. Greenroofs. Available online: http://www.greenroofs.com/content/articles/147-Vertical-School-GardensEducational-Successes-in-Barcelona.htm\#.VvADneLhCM9 (accessed on 11 June 2016).

86. Brković, M. Savremene obrazovne ustanove-Koraci ka Ekološkoj Održivosti [Contemporary Educational Institutions—Steps towards Environmental Sustainability]. Izgradnja 2013, 67, 564-573.

87. Brković, M.; Parnell, R. Schools as 3D Textbooks for Sustainability Education. In Education, Space and Urban Planning; Million, A., Heinrich, J.A., Coelen, T., Eds.; Springer: Cham, Switzerland, 2017; pp. 79-90. [CrossRef]

88. McCullough, M.B.; Martin, M.D.; Sajady, M.A. Implementing Green Walls in Schools. Front. Psychol. 2018, 9. [CrossRef] 
89. Mayrand, F.; Clergeau, P. Green Roofs and Green Walls for Biodivesity Conservation: A Contribution to Urban Connectivity? Sustainability 2018, 10, 985. [CrossRef]

90. Veisten, K.; Smyrnova, Y.; Klæboe, R.; Hornikx, M.; Mosslemi, M.; Kang, J. Valuation of Green Walls and Green Roofs as Soundscape Measures: Including Monetised Amenity Values Together with Noise-attenuation Values in a Cost-benefit Analysis of a Green Wall Affecting Courtyards. Int. J. Environ. Res. Public Health 2012, 9, 3770-4240. [CrossRef] [PubMed]

91. Haggag, M.; Hassan, A. Cost-Benefit Analysis of Living Wall Systems on School Building Skins in a Hot Climate. WIT Trans. Ecol. Environ. V 2015, 206, 3-11. [CrossRef]

92. Perini, K.; Rosasco, P. Cost Benefit Analysis for Green Facades and Living Wall Systems. Build Environ. 2013, 70, 110-121. [CrossRef]

93. Johnston, J.; Newton, J. Building Green: A Guide for Using Plants on Roofs, Walls and Pavements, 1st ed.; Greater London Authority: London, UK, 1996; ISBN 1852616377.

(C) 2019 by the authors. Licensee MDPI, Basel, Switzerland. This article is an open access article distributed under the terms and conditions of the Creative Commons Attribution (CC BY) license (http://creativecommons.org/licenses/by/4.0/). 